\title{
PERAN IKLAN LAYANAN MASYARAKAT \\ DALAM SOSIALISASI PROGRAM BUSWAY OLEH PEMPROV DKI: PROSES SOSIALISASI PROGRAM BUSWAY
}

\author{
Didier Neonisa \\ Jurusan Marketing Communication, Fakultas Ekonomi dan Komunikasi, BINUS University \\ Jln. K.H. Syahdan No. 9, Palmerah, Jakarta Barat 11480
}

\begin{abstract}
This research is based on the increasing numbers for traffic level in Jakarta and also less facilitated mass transportation; therefore the district government of DKI Jakarta built another mass transportation (busway) as one solution for the problems. The local government of DKI Jakarta uses mass media, especially television, to socialize the busway transportation for community. The method in this research is descriptive qualitative along with interview and related documentation as data gathering technique. The research uses theories like mass communication theory, including mass media, television, and advertising. The research result is known that public service advertising has a big role for the government of DKI Jakarta as socialization media for busway transportation; however that does not followed by the right socialization process.
\end{abstract}

Keywords: public service advertising, busway, transportation, television

\begin{abstract}
ABSTRAK
Penelitian ini dilatarbelakangi oleh tingginya tingkat kemacetan di kota Jakarta dan juga sarana transportasi massa yang kurang memadai, sehingga pemerintah provinsi DKI Jakarta membangun sarana transportasi baru, yaitu busway sebagai solusi untuk mengatasi permasalahan tersebut. Pemerintah provinsi DKI Jakarta menggunakan media massa yaitu iklan layanan masyarakat di media televisi sebagai salah satu sarana sosialisasi program transportasi busway kepada masyarakat. Metode penelitian yang digunakan dalam penelitian ini adalah metode penelitian kualitatif deskriptif dengan wawancara dan dokumentasi sebagai metode pengumpulan data. Teori yang digunakan dalam penelitian ini yaitu teori komunikasi massa yang mencakup media massa, televisi dan periklanan. Kemudian teori komunikasi persuasi dan proses PR empat langkah sebagi teori pendukung. Hasil dari penelitian ini diketahui bahwa iklan layanan masyarakat memiliki peran yang besar bagi pemerintah provinsi DKI Jakarta sebagai sarana sosialisasi program transportasi busway, namun hal tersebut tidak didukung dengan proses sosialisasi yang tepat.
\end{abstract}

Kata kunci: iklan layanan masyarakat, busway, transportasi, televisi 


\section{PENDAHULUAN}

Tingginya angka populasi masyarakat kota jakarta berimbas pada tingkat pertumbuhan kendaraan di kota ini, Menurut data dari Komisi Kepolisian Indonesia (2009), perbandingan angka kepemilikan kendaraan di kota Jakarta sangat tinggi, yaitu 9.993.867, sedangkan jumlah penduduk di kota Jakarta sekitar 8.513.385. Dari data tersebut, dapat disimpulkan bahwa hampir setiap warga Jakarta memiliki lebih dari satu kendaraan pribadi. Dalam Ardiansyah (2010), dituliskan bahwa tercatat pada tahun 2010, di Jakarta, setiap hari lahir 240 mobil dan 890 unit sepeda motor baru.Sayangnya, pertumbuhan ruas jalan di Jakarta tidak sebanding. Panjang jalan di Jakarta hanya $7.650 \mathrm{~km}$ dan luas jalan 40,1 km atau 0,26 persen dari luas wilayah DKI.

Sebagai jalan keluar Pemerintah Provinsi DKI Jakarta, berusaha meningkatakan pelayanan dari angkutan umum masal, seperti yang diungkapkan Fauzi Bowo Gubernur DKI (dalam Erna, 2011): "Dalam rencana anggaran tahun 2011, tetap menjadi prioritas besar untuk mengurangi kemacetan di Jakarta. Diantaranya kita akan memberikan perhatian besar kepada peningkatan angkutan umum massal. Andalan kita masih tetap busway. Kita akan tingkatkan pelayanannya dari segala sisi.” Demi mencapai tujuan tersebut Pemprov DKI Jakarta berusaha untuk mengajak masyarakat menggunakan sarana transportasi busway untuk aktivitas sehari-hari. Dengan menggunakan iklan layanan masyarakat melalui media televisi mereka berusaha mensosialisasikan program busway untuk menarik perhatian masyarakat.

Penelitian lain membuktikan bahwa televisi adalah media yang paling dipercaya, bahkan paling disukai jika seseorang hanya memiliki satu media saja, dan dianggap memberikan penyajian terbaik dibanding semua media yang ada dan bahwa TV memimpin dalam bidang ini sejak 1959 sampai 1967 (Roper dalam Blake \& Haroldsen, 1979). Menurut Lee \& Johnson (2007), di media televisi terdapat beberapa jenis periklanan, seperti periklanan produk, periklanan politik, dan periklanan pelayanan masyarakat. Periklanan layanan masyarakat dirancang untuk beroperasi untuk kepentingan masyarakat dan mempromosikan kesejahteraan masyarakat.

Pertanyaan yang mendasari penelitian ini adalah: (1) bagaimana peran iklan layanan masyarakat sebagai sarana sosialisasi program transportasi busway; dan (2) bagaimana proses perencanaan sosialisasi program transportasi busway. Sementara itu, tujuan penelitian ini yaitu untuk mengetahui peranan iklan layanan masyarakat bagi Pemprov DKI dalam sosialisasi program transportasi busway, serta untuk mengetahui proses sosialisasi yang dilakukan oleh Pemprov DKI.

Manfaat penelitian ini yaitu untuk mengetahui faktor keunggulan iklan layanan masyarakat dalam media televisi dan untuk mengetahui cara Pemprov DKI Jakarta untuk menarik perhatian masyarakat melalui iklan layanan masyarakat. Dalam penelitian yang dilakukan dilakukan oleh Furi Himawanto pada tahun 2003, berusaha membahas mengenai dampak iklan antirokok terhadap para remaja jakarta. Penelitian ini dilatarbelakangi oleh kebiasaan merokok merupaka salah satu masalah kesehatan publik yang menjadi agenda penting World Health Organization (WHO).

Industri rokok berusaha berperan untuk menanggulangi kebiasaan merokok sebagai bentuk tanggung jawab sosial mereka kepada publik. Hal itu diperlihatkan oleh dua perusahaan rokok terkenal di dunia, Phillip Morris dan Japan Tobacco international berkerjasama dalam kegiatan yang bertajuk Youth Smoking Prevention. Dalam kegiatan ini kedua perusahaan tersebut membuat iklan internasional yang ditayangkan oleh Music television (MTV) dengan tujuan mempengaruhi anak-anak dan remaja di bawah usia 18 tahun agar tidak merokok.

Fenemona menarik tersebut yang menjadi dasar penelitian yang dilakukan penulis, untuk mengetahui bagaimana pola hubungan faktor-faktor yang mempengaruhi dampak tayangan iklan layanan masyarakat antirokok terhadap kognisi dan intense remaja untuk tidak merokok dan juga untuk mengungkapkan hubungan faktor-faktor yang mempengaruhinya. Penulis menggunakan teori 
perlindungan diri untuk menganalisa kebiasaan merokok para remaja, teori ini membahas mengenai motivasi seseorang untuk melindungi dirinya dari penyakit. Menurut teori ini, individu dapat dimotivasi melakukan perilaku yang direkomendasikan tidak hanya untuk menghindari resiko kesehatan, tetapi juga resiko sosial atau interpersonal.

Dari 122 responden yang berasal dari SMUN 103 Jakarta mengaku pernah menonton ataupun melihat iklan antirokok yang ditayangkan oleh MTV. Namun dari hasil penelitian tersebut, iklan antirokok tidak serta merta merubah sikap mereka terhadap iklan, hal ini dikarenakan dari sebelum pembuatan iklan tersebut, mereka sudah mengerti akan bahaya merokok. Selain itu terdapat faktor lain yang lebih kuat dalam menentukan sikap dan prilaku para remaja, seperti faktor lingkungan dan kelompok bermain. Selain hal tersebut, kesulitan iklan untuk mempengaruhi dan mengubah prilaku para remaja tersebut, karena mereka sudah mempunyai keyakinan sendiri bahwa mereka tidak akan terkena dampak negatif (gangguan kesehatan) dari bahaya merokok. Pemikiran keyakinan yang sudah terbentuk di dalam benak setiap orang tentunya sulit dirubah begitu saja hanya dengan menyaksikan tayangan iklan di televisi.

Namun di sisi lain, iklan yang menampilkan tema remaja terlihat keren tanpa merokok, mungkin saja berhasil dalam meyakinkan seseorang yang tidak merokok memiliki sisi yang lebih baik dalam hal kesehatan jika dia tidak merokok kedepannya. Selain itu, iklan antirokok ini dapat saja berhasil bagi mereka yang memang belum mengenal rokok, berdasarkan variabel yang sudah dijabarkan sebelumnya, para remaja yang belum mengenal rokok akan merasa lebih baik dan menjauhkan dirinya dari kerugian yang ditibulkan dari prilaku merokok, baik resiko kesehatan maupun resiko sosial.

\section{Teori Komunikasi Massa dan Iklan}

Menurut Bittner (dalam Ardianto \& Erdinaya, 2004), komunikasi massa adalah pesan yang dikomunikasikan melalui media massa pada sejumlah besar orang. Dengan demikian, maka unsurunsur penting dalam komunikasi massa adalah: komunikator, media massa, informasi (pesan massa), gatekeeper, khalayak, dan umpan balik. Teori ini diyakini dapat membantu penulis dalam menganalisa penyampaian pesan yang dilakukan oleh pemprov DKI Jakarta, melalui iklan layanan masyarakat (media televisi). "Iklan merupakan penyajian dan promosi mengenai suatu produk, jasa, atau ide yang penyajian dan promosinya itu dilakukan dan dibayar oleh suatu sponsor” (Blake \& Haroldsen, 2003, p. $66)$.

Menurut Gema Pariwara (2011), Iklan mengandung enam prinsip dasar, yaitu: (1) adanya pesan tertentu, sebuah iklan tidak akan ada tanpa adanya pesan. Tanpa pesan, iklan tidak akan berwujud. Pesan yang disampaikan oleh sebuah iklan, dapat berbentuk perpaduan antara pesan verbal dan pesan non verbal; (2) dilakukan oleh komunikator (sponsor), pesan iklan ada karena dibuat oleh komunikator. Sebaliknya bila tidak ada komunikator maka tidak ada pesan iklan; (3) dilakukan dengan cara nonpersonal, artinya tidak dalam bentuk tatap muka. Penyampaian pesan dapat disebut iklan bila dilakukan melalui media (yang kemudian disebut dengan media periklanan); (4) disampaikan untuk khalayak tertentu, iklan diciptakan oleh komunikator karena ingin ditujukan kepada khalayak tertentu. Dalam dunia periklanan, khalayak sasaran cenderung bersifat khusus. Pesan yang disampaikan tidak dimaksudkan untuk diberikan kepada semua orang, melainkan kelompok target audience tertentu; (5) dalam menyampaikan pesan tersebut, dilakukan dengan cara membayar. Dalam kegiatan periklanan, istilah membayar sekarang ini harus dimaknai secara luas. Sebab, kata membayar tidak saja dilakukan dengan alat tukar uang, melainkan dengan cara barter berupa ruang, waktu, dan kesempatan; (6) penyampaian pesan tersebut mengharapkan dampak tertentu, dalam sebuah visualisasi iklan, seluruh pesan dalam iklan semestinya merupakan pesan yang efektif. Artinya, pesan yang mampu menggerakkan khalayak agar mereka mengikuti pesan iklan. 
Sebuah pesan iklan disebut efektif bila pesan tersebut mampu menggambarkan apa yang dikehendaki oleh komunikator secara tepat dan apa yang dituangkan dalam pesan iklan tersebut mampu dipersepsi secara sama oleh khalayak dengan apa yang dikehendaki oleh komunikator. Iklan layanan masyarakat atau dalam bahasa inggris dikenal sebagai public service advertising (PSA) adalah jenis periklanan yang dilakukan oleh suatu organisasi komersial maupun non-komersial (pemerintah) untuk mencapai tujuan sosial atau sosio-ekonomis. "Periklanan pelayanan masyarakat dirancang untuk beroperasi untuk kepentingan masyarakat dan mempromosikan kesejahteraan masyarakat” (lee dan Johnson, 2004: 9)

Menurut Widyatama (2005), "Iklan layanan masyarakat adalah iklan yang digunakan untuk menyampiakan informasi, mempersuasi atau mendidik khalayak dimana tujuan akhir bukan untuk mendapatkan keuntungan ekonomi, melainkan keuntungan sosial. Keuntungan sosial yang dimaksud adalah munculnya penambahan pengetahuan, kesadaran sikap dan perubahan prilkaumasyarakat terhadap masalah yang diiklankan, serta mendapatkan citra baik di mata masyarakat” (p. 102).

\section{Teori Komunikasi Persuasi}

Dalam penelitian ini penulis menggunakan teori komunikasi persuasi sebagai teori pendukung dalam penelitian yang sedang dilakukan. Teori komunikasi persuasi merupakan teori yang berkaitan erat dengan periklanan. Menurut DeVito (dalam Ardianto \& Erdinaya, 2004), fungsi komunikasi massa secara khusus adalah: "meyakinkan (to persuade), menganugerahkan status, membius (narcotization), menciptakan rasa kebersatuan, privatisasi dan hubungan parasosial.”

Menurut Olson \& Zanna (dalam Severin \& Tankard, 2005), persuasi adalah "perubahan sikap akibat paparan informasi dari orang lain” (p. 177). Dengan menggunakan teori ini penulis ingin melihat efek dari layanan maysyarakat yang di inginkan oleh Pemprov DKI dalam melakukan sosialisasi program busway.

Dalam Severin \& Tankard (2005), sikap itu sendiri terdiri dari tiga komponen dasar, yaitu: (1) komponen kognitif, keyakinan terhadap sebuah objek; (2) komponen afektif, kesukaan atau perasaan terhadap sebuah objek; dan (3) komponen perilaku, tindakan terhadap objek. Tujuan dari teori ini adalah penulis ingin menganalisis sampai di tahap mana perubahan sikap yang terjadi akibat dari program sosialisais busway yang di jalakan oleh Pemprov DKI

\section{Proses Public Relations}

Proses public relations (PR) empat langkah merupakan langkah yang akan diambil oleh sebuah PR untuk menyelesaikan permasalahan yang dihadapi oleh suatu organisasi. Penulis menggunakan model ini untuk menganalisa bagaimana proses perencanaan komunikasi yang dilakukan oleh pemprov DKI (Diskominfomas DKI) sesuai dengan tujuan yang mereka inginkan atau tidak. Terdapat empat langkah yang akan dilakukan oleh sebuah PR dalam merencanakan strategi yang akan diambil dalam penyelesaian masalah (Broom, 2008), yaitu: (1) definisikan permasalahan, dalam tahap ini Public Relations perlu melibatkan diri dalam penelitian dan pengumpulan fakta. Selain itu Public Relations perlu memantau dan membaca terus pengertian, opini, sikap dan prilaku mereka yang berkepentingan dan terpengaruh oleh sikap dan tindakan perusahaan. Tahap ini merupakan penerapan atau fungsi intelijen perusahaan. Langkah ini dilakukan oleh seorang Public Relations setiap saat bukan hanya pada saat krisis terjadi. (2) Perencanaan dan program, pada tahap ini seorang Public Relations sudah menemukan penyebab timbulnya permasalahan dan sudah siap dengan langkah-langkah pemecahan dan pencegahan. Langkah-langkah ini dirumuskan dalam bentuk rencana dan program, termasuk anggarannya. (3) Aksi dan komunikasi, tahap ini merupakan tahap pelaksanaan/kegiatan sesuai dengan fakta dan data yang telah dirumuskan dalam bentuk perencanaan. Pada tahap ini, aksi dan komunikasi harus dikaitkan dengan objective dan goals yang spesifik; (4) 
Evaluasi dan program, proses Public Relations selalu dimulai dari mengumpulkan fakta dan diakhiri pula dengan pengumpulan fakta. Untuk mengetahui prosesnya sudah selesai belum, seorang Public Relations perlu melakukan evaluasi atas langkah-langkah yang telah diambil (pengukuran).

Penulis mengunakan teori proses PR empat langkah untuk menganalisa bagaimana proses sosialisasi yang telah dilakukan oleh pemprov DKI Jakarta dalam mensosialisasikan transportasi busway dengan menggunakan iklan layanan masyarakat di media televisi.

\section{METODE}

Metode penelitian yang digunakan dalam skripsi ini adalah metode penelitian kualitatif. Menurut Kiriyantono (2007), "riset kualitatif bertujuan untuk menjelaskan fenomena dengan sedalamdalamnya melalui pengumpulan data sedalam-dalamnya” (p. 58). Menurut Bodgan \& Taylor dalam (Moleong, 2006), mendefinisikan metodologi kualitatif sebagai "prosedur penelitian yang menghasilkan data deskriptif berupa kata-kata tertulis atau lisan dari orang-orang dan perilaku yang dapat diamati” (p. 4).

Dalam penelitian ini, penulis mengambil dua narasumber sebagai sumber data dalam penelitian ini. Pemilihan narasumber ini didasarkan pada kriteria yang penulis tentukan, seperti lama berkerja dalam perusahaan, jabatan, dan pengetahuan di bidang yang penulis ambil sebagai objek penelitian.

Narasumber inti yang pertama dalam penelitian yang penulis lakukan adalah kepala bagian media massa Diskominfomas Pemprov DKI Jakarta yaitu bapak Rinta Afdalita Imron. Bapak rinta telah berkerja di bagian diskominfomas pemprov DKI Jakarta selama 15 tahun, dan sudah 2 tahun menjadi kepala bagian media massa diskominfomas pemprov DKI Jakarta. Selain itu, pemilihan narasumber ini didasarkan dengan alasan iklan layanan masyarakat tersebut merupakan tugas dari dinas komunikasi dan informasi masyarakat (Diskominfomas). Sementara itu, narasumber kedua yang penulis wawancarai adalah staf diskominfomas DKI Jakarta bagian media massa di bidang penyiapan materi dan publikasi dan sekaligus bagian dari tim kerja dari program sosialisasi transportasi busway, yaitu bapak Yuliarto. Bapak yuliarto telah berkerja di bagian diskominfomas pemrov DKI Jakarta selama 10 tahun dan menjadi bagian dari tim kerja pada sosialisasi transportasi busway.

Teknik pengumpulan data dalam penelitian ini menggunakan teknik wawancara mendalam dan dokumentasi. Pemilihan teknik ini didasarkan kepada kedalaman data yang ingin diperoleh oleh penulis. Penulis ingin mengetahui secara mendalam mengenai peran iklan layanan masyarakat dalam media telvisi sebagai sarana sosialisasi program transportasi busway bagi Pemprov DKI.

\section{HASIL DAN PEMBAHASAN}

Untuk memudahkan pembaca dalam melihat hasil pembahasan, penulis mengelompokkan pernyataan atau hasil wawancara yang sejenis dan akan dibahas dengan teori yang penulis gunakan.

\section{Bentuk Sosialisasi}

Dalam melaksanakan suatu program sosialisasi, pemprov DKI Jakarta bermaksud untuk menyampaikan pesan kepada masyarakat. Untuk melakukan program sosialisasi tersebut, pemprov DKI Jakarta dapat melakukan sosialisasi secara langsung kepada masyarakat atau dengan 
menggunakan media sebagai sarana sosialisasi. Terkait sosialisasi program transportasi busway, pemprov DKI Jakarta mengutamakan melakukan sosialisasi menggunakan media massa sebagai sarana sosialisasi.

Pemerintah Provinsi DKI Jakarta dalam mensosialisasikan Busway selain melalui media massa juga melalui Tatap muka secara langsung kepada masyarakat. Tatap muka ini dilaksanakan ditingkat kecamatan dengan menghadirkan narasumber yang memahami tentang Busway. Sosialisasi melalui tatap muka ini guna mendapatkan masukan secara langsung dari masyarakat. Namun demikian disadari bahwa sosialisasi melalui tatap muka hanya untuk melengkapi sosialisasi melalui media massa.

Pengutamaan media massa sebagai sarana sosialisasi program transportasi busway ini tidak terlepas dari sasaran penyampian informasi ini adalah masyarakat luas. Sehingga dibutuhkan sebuah cara yang dapat menyampaikan pesan ini kepada masyarakat tersebut. Sesuai dengan teori komunikasi massa, menurut Bittner (dalam Ardianto \& Erdinaya, 2004), "komunikasi massa adalah pesan yang dikomunikasikan melalui media massa pada sejumlah besar orang (mass communication is messages communicated through a mass medium to large number of people)” (p. 3).

Proses sosialisasi yang dilakukan oleh pemprov DKI Jakarta merupakan sebuah proses komunikasi massa, hal itu dikarenakan proses komunikasi tersebut dilakukan dari komunikator yang menyampaikan pesan kepada khalayak luas (masyarakat) dan menggunakan media massa sebagai saluran penyampaian pesan. "Komunikasi massa adalah proses komunikasi yang dilakukan melalui media massa dengan berbagai tujuan komunikasi dan untuk menyampaikan informasi kepada khalayak luas” (Bungin, 2007, p. 71).

Penggunaan media massa sebagai sarana sosialisasi merupakan salah satu peran dari pada media massa itu sendiri, Sebagai intitusi pencerahan masayrakat, yaitu perannya sebagai media edukasi. "Media massa merupakan sebuah perantara publik. Biasanya media massa dianggap sebagai sumber informasi dan berita, sebagai forum persuasi maupun hiburan” (Vivian, 2008, pp. 4-7).

Dari pembahasan tersebut penulis menarik kesimpulan bahwa pemilihan media massa sebagai sarana sosialisasi program transportasi busway dikarenakan pemprov DKI Jakarta ingin menyampaikan pesan kepada masyarakat luas, sehingga penggunaan media massa sebagai saluran penyampaian pesan merupakan pilihan yang tepat bagi pemprov DKI Jakarta. Penggunaan media massa sebagai sarana sosialisasi program transportasi busway ini sesuai dengan prinsip pemprov DKI jakarta, dengan dana yang terbatas tetapi program sosialisasi mengenai transportasi busway ini dapat mencakup masyarakat luas. Seperti yang diungkapkan oleh Bapak Rinta: "Prinsip pemprov DKI Jakarta dalam mensosialisasikan kebijakan atau program kepada masyarakat adalah dengan dana yang terbatas namun dapat menjangkau warga seluas-luasnya atau sebanyak mungkin. Untuk itu pemilihan sosialisasi melalui media massa, bagi kami merupakan pilihan yang paling efektif.”

Hal ini sesuai dengan proses komunikasi massa menurut McQuail dalam Bungin (2007), "melakukan distribusi dan penerimaan informasi dalam skala besar, jadi proses komunikasi massa melakukan distribusi informasi kemasyarakatan dalam skala yang besar, sekali siaran, pemberitaan yang disebarkan dalam jumlah yang luas, dan diterima oleh massa yang besar pula.”

Selain itu, dari pernyataan tersebut media massa menjalankan salah satu perannya yaitu menjadi media informasi, "media yang setiap saat menyampaikan informasi kepada masyarakat. dengan informasi yang terbuka dan jujur dan benar disampaikan media massa kepada masyarakat, maka masyarakat akan menjadi masyarakat yang kaya dengan informasi. Selain itu informasi yang banyak dimiliki oleh masyarakat, menjadikan masyarakat sebagai masyarakat dunia yang dapat berpartisipasi dengan berbagi kemampuannya” (Bungin, 2007, p. 85). Dari pembahasan tersebut penulis menarik kesimpulan bahwa media massa menjalankan perannya yaitu sebagai penyalur 
informasi kepada masyarakat luas. Sehingga pemilihan media massa sesuai dengan prinsip pemprov DKI Jakarta dalam melakukan suatu sosialisasi program, dengan dana yang terbatas namun dapat menjangkau warga seluas-luasnya.

\section{Media Televisi}

Media massa terdari dari tiga jenis, yaitu media cetak, media elektronik dan media internet. Seperti yang penulis kutip dari Rogers dalam Bungin (2007), mengatakan "bahwa dalam hubungan komunikasi dimasyarakat, dikenal empat era komunikasi, yaitu: era tulis, era media cetak, era media telekomunikasi, dan era media komunikasi interaktif. Dalam era terkahir ini media komunikasi interaktif dikenal media komputer, videotext, dan teletext, teleconfrencing, tv kabel, dan sebagainya” (p. 111).

Dari ketiga media massa yang ada, pemprov DKI Jakarta lebih mengandalkan media televisi sebagai sarana sosialisasi program transportasi busway. Seperti penuturan dari bapak Rinta: “...ketiga jenis media tersebut merupakan media yang kami andalkan untuk dapat memberikan informasi kepada masyarakat, namun harapan kami lebih besar di media televisi sebagai sarana sosialisasi program transportasi busway. Hal tersebut dikarenakan hampir dari seluruh masyarakat Jakarta lebih menyukai menonton televisi dibandingkan dengan media lainnya. Sehingga informasi yang kami sampaikan dapat mencakup masyarakat luas.”

Pemprov DKI Jakarta mengandalkan media televisi sebagai sarana yang diyakini dapat menyampaikan pesan dengan baik kepada masyarakat. Penggunaan media televisi ini berdasarkan kepada masyarakat Jakarta lebih menyukai menonton televisi dibandingkan dengan mendengarkan radio ataupun membaca koran. Hal ini sesuai dengan penelitian yang penulis kutip dari Roper (dalam Blake \& Haroldsen, 2003), bahwa penelitian lain membuktikan bahwa "televisi adalah media yang paling dipercaya, bahkan paling disukai jika seseorang hanya memiliki satu media saja, dan dianggap memberikan penyajian terbaik dibanding semua media yang ada dan bahwa TV memimpin dalam bidang ini sejak 1959 sampai 1967” (p. 42).

Selain dari pada penelitian yang membuktikan bahwa memang lebih banyak orang yang menyukai media televisi dibandingkan dengan media lainnya, media televisi sendiri memiliki keunggulan dibandingkan media lainnya, seperti yang diutarakan oleh Bapak Rinta: “...menurut saya, Keunggulan media televisi dibanding dengan media lainnya yaitu, Pesan-pesan yang disampaikan melalui media televisi dapat menjangkau audience dalam hal ini masyarakat (public penonton TV) secara serempak dan menjangkau audience dengan seluas-luasnya dan sebanyak-banyak, kemudian juga Pesan yang disampaikan melalui media televisi lebih mudah dipahami oleh masyarakat. Karena penyampaiannya disamping secara audio juga dilengkapi dengan video. Dan pengemasan pesan-pesan melalui PSA di media televisi cenderung lebih mudah.”

Penuturan Bapak Rinta sesuai dengan teori yang membahas mengenai kelebihan media televisi. Menurut Karlinah, Soemirat \& Komala (1999), televisi mempunyai kelebihan dapat dilihat sekaligus didengar, tidak hanya seperti radio yang hanya dapat didengar atau majalah yang hanya dapat dilihat. Oleh karena itu tidak salah bila lebih banyak orang yang lebih menyukai menonton televisi dibandingkan dengan mendengar radio ataupun membaca koran.

Selain itu, menurut Kuswandi (2008), "televisi adalah salah satu hiburan dan informasi yang berkembang pesat di dunia dan di indonesia. Televisi menyuguhkan visualisasi yang tidak dapat diberikan media massa lain seperti radio dan surat kabar. Media televisi berperan sebagai alat informasi, hiburan, kontrol sosial dan penghubung wilayah secara geografis” (p. 47). Dari pembahasan penulis menarik kesimpulan bahwa keunggulan televisi yang menyajikan tayangan audio-visual menjadikan media televisi merupakan media yang lebih diandalkan dibandingkan dengan media lainnya sebagai sarana sosialisasi kepada masyarakat terkait program transportasi busway. 


\section{Iklan Layanan Masyarakat dalam Media Televisi}

Dalam media televisi terdapat tayangan iklan layanan masyarakat, tayangan iklan layanan masyarakat ini merupakan salah satu bentuk tayangan yang menjadi sarana sosialisasi dari pemprov DKI Jakarta. Seperti yang diutarakan oleh Bapak Yuliarto: "Menurut pandangan saya, media televisi memiliki beberapa keunggulan diantara media lainnya, seperti penyampaian pesan atau informasi iklan layanan masyarakat melalui media televisi mudah dipantau. Jadwal penayangan iklan layanan masyarakat PSA Busway di media televisi dapat disesuaikan dengan kebutuhan dan keinginan Pemerintah Provinsi DKI Jakarta.”

Jadwal penayangan iklan layanan masyarakat dapat disesuaikan dengan keinginan pemprov DKI Jakarta, sehingga penyangan iklan layanan masyarakat tersebut dapat dilakukan secara efektif. Hal ini sesuai dengan teori, menurut Lee \& Johnson (2004), "Iklan televisi bisa ditayangkan beberapa kali dalam sehari sampai dipandang cukup bermanfaat yang memungkinkan sejumlah masyarakat untuk menyaksikannya, dan dalam frekuensi yang cukup sehingga pengaruh iklan itu muncul” (p. 267).

Penggunaan iklan layanan masyarakat diharapkan mampu untuk menyampaikan pesan kepada masyarakat luas dibandingkan dengan tayangan media televisi lainnya seperti running text dan dialog interaktif. Seperti yang diutarakan oleh Bapak Rinta: “Adapun program televisi yang dapat dimanfaatkan untuk mensosialisasikan Busway antara lain, pentayangan Filler atau iklan layanan masyarakat, dialog interaktif, telops, Running Teks. Diantara program tersebut diatas, pilihan yang mudah murah namun dampaknya sangat tinggi yaitu sosalisasi melalui pentayangan Filler (Iklan layanan Masyarakat). Melalui tayangan dialog televisi memang penonton dapat memperoleh informasi lebih lengkap, Namun demikain program dialog, biasanya berdurasi minimal 10 menit. Kondisi ini tidak menutup kemungkinan akan membosankan penonton. Sehingga tayangan Busway melalui dialog televisi dapat ditinggalkan oleh penonton. Sementara sosialisasi melalui tayangan PSA atau filler, walaupun durasi hanya sebentar namun dengan kemasan yang lengkap dan menarik, maka pesan yang disampaikan cenderung lebih efektif, selain itu juga iklan layanan masyarakat dapat ditayangkan jauh lebih banyak dibandingkan dengan program dialog televisi yang hanya sekali tayang. Faktor yang tidak kalah pentingnya yaitu biaya untuk tayang PSA lebih murah dan mudah dibanding melalui dialog televisi.”

Penuturan Bapak Rinta mengenai penggunaan iklan layanan masyarakat lebih diandalkan oleh pihak pemprov DKI Jakarta, sesuai dengan teori Iklan televisi bisa ditayangkan beberapa kali dalam sehari dan dalam frekuensi yang cukup sehingga pengaruh iklan itu muncul. "Sekarang ini para pembuat iklan televisi tidak lagi membuat iklan yang panjang-panjang, mereka justru membuat iklan pendek dan menarik. Agar ketika ditayang ulang, pemirsa tidak cepat bosan” (Lee \& Johnson, 2004, p. 267). Dalam hal tersebut, iklan dalam media televisi menjalankan salah satu fungsinya yaitu sebagai “media periklanan menjalankan sebuah fungsi informasi” (Lee \& Johnson, 2004, p. 10), seperti yang sudah dibahas sebelumnya, iklan tidak saja menjual produk, melainkan memberikan informasi dan pembelajaran kepada masayrakat.

Menurut Widyatama (2005), iklan layanan masyarakat adalah iklan yang digunakan untuk menyampaikan informasi, mempersuasi atau mendidik khalayak dimana tujuan akhir bukan untuk mendapatkan keuntungan ekonomi, melainkan keuntungan sosial. Keuntungan sosial yang dimaksud adalah munculnya penambahan pengetahuan, kesadaran sikap dan perubahan prilkau masyarakat terhadap masalah yang diiklankan, serta mendapatkan citra baik di mata masyarakat.

Dari keunggulan tersebut tidak salah bila diskominfomas pemprov DKI Jakarta mengandalkan iklan layanan masyarakat dalam menyampaikan informasi kepada masyarakat mengenai trasnportasi busway. Selain itu, dengan menggunakan iklan layanan masyarakat, pengemasan iklan cenderung lebih mudah, karena ditampilkan dengan visualisasi (gambar). Seperti yang diutarakan oleh Bapak 
Yuliarto: "Dalam mengemas pesan-pesan melalui iklan layanan masyarakat (PSA) ini lebih mudah dibanding dengan dialog melalui televisi. Karena pesan-pesan yang disampaikan melalui PSA sedikit kata-kata namun lebih banyak menampilkan gambar.” Hal tersebut sesuai dengan penjelasan teori yang ada, pembuat acara televisi harus dapat menyampaikan gagasan atau informasi dalam bentuk gambar. Oleh karena itu, "komunikator harus dapat berfikir dalam gambar sehingga pesan yang ingin disampaikan dapat diterima dengan baik oleh komunikan” (Kalinah, 2007: 3.8-4.0).

\section{Pemilihan Stasiun Televisi}

Pemilihan stasiun televisi yang akan menayangkan iklan layanan masyarakat mengenai trasnportasi busway ini tentunya akan mempengaruhi tingkat keefektifan dari program sosialisasi yang dilakukan. pemilihan stasiun televisi TV One dan Metro TV sebagai stasiun yang menayangkan iklan layanan masyarakat mengenai transportasi busway ini didasari pada kriteria dan anggaran yang telah ditentukan, seperti yang diutarakan oleh Bapak Rinta: "Jadi begini, dalam memilih media yang akan menyiarkan iklan busway ini, kami tidak memiliki perencanaan, namun kami memiliki beberapa kriteria dalam pemilihan media yang akan menyiarkan iklan pemprov DKI, dan kedua stasiun televisi tersebut sesuai dengan criteria yang pihak kami tentukan, seperti Metro TV dan TV One itu media televisi yang misinya sebagian besar untuk menyampaikan informasi yang bersifat informatif dibandingkan hiburan. Hal ini dapat dilihat bahwa program yang disajikan di TV One dan Metro TV sedikit menayangkan senetron atau music. Penonton TV One dan Metro TV cenderung tingkat ekonominya termasuk kelompok menengah keatas, Sedangkan masyarakat yang menggunakan kendaraan pribadi cenderung kelompok menengah keatas. Selain itu, pada jam-jam sibuk (prime time) di stasiun Metro TV dan TV One lebih banyak menyajikan program televisi yang bersifat informatif.”

Kriteria tersebut sesuai dengan teori yang ada, media sebagai intitusi pencerahan masyarakat, yaitu perannya sebagai media edukasi. Media massa menjadi media yang setiap saat mendidik masyarakat supaya cerdas, terbuka pikirannya, dan menjadi masyarakat yang maju. Sehingga pemilihan kedua stasiun televisi ini lebih dikarenakan tayangan dari TV One dan metro tv yang sifatnya lebih informatif dan mendidik. Selain itu Metro TV dan TV One lebih banyak ditonton oleh masyarakat kelas menengah, hal ini sesuai dengan target audience utama dari sosialisasi yang dilakukan. Hal tersebut sesuai dengan teori mengenai prinsip iklan yaitu "Iklan diciptakan oleh komunikator karena ingin ditujukan kepada khalayak tertentu. khalayak sasaran cenderung bersifat khusus. Pesan yang disampaikan tidak dimaksudkan untuk diberikan kepada semua orang, melainkan kelompok target audience tertentu” (Gema Pariwara, 2011).

Ditambahkan oleh Bapak Yuliarto mengenai alasan pemilihan stasiun televisi Metro TV dan TV One: “...yaa pemilihan ini, berdasarkan tayangan dalam Metro TV dan TV One sarat akan berita dan informasi yang bersifat mendidik. Mereka lebih memperbanyak tayangan yang sifatnya berupa penyebaran informasi dibandingkan tayangan sinetron atau hiburan lainnya. Ini menjadi pertimbangan utama kami dalam memilih kedua stasiun televisi tersebut.”

Dari kedua pernyataan tersebut dapat disimpulkan bahwa pemilihan kedua stasiun televisi ini didasarkan pada tayangan-tayangan dari metro tv dan tv one yang sifatnya lebih mendidik dan memberikan informasi dibandingkan dengan hiburan, hal sesuai dengan teori dari peran media massa yaitu "Sebagai intitusi pencerahan masyarakat, yaitu perannya sebagai media edukasi. Media massa menjadi media yang setiap saat mendidik masyarakat supaya cerdas, terbuka pikirannya, dan menjadi masyarakat yang maju” (Bungin, 2006). Penayangan iklan layanan masyarakat mengenai transportasi busway ini ditayangkan pada saat prime time, hal ini bertujuan agar lebih banyak masayarakat yang melihat tayangan iklan layanan masyarakat ini, hal ini sesuai dengan pembahasan bahwa "iklan televisi dinikmati dirumah-rumah dalam suasana yang serba santai atau reaktif, maka pemirsa lebih siap untuk memberikan perhatian” (Lee \& Johnson, 2004, p. 267). Sehingga iklan layanan masyarakat ini diharapkan dapat menarik perhatian masyarakat luas untuk menonton dan menerima pesan yang disampaikan. 


\section{Pesan yang Ingin Disampaikan}

Namun, sosialisasi melalui media televisi, khususnya iklan layanan masyarakat terbentur dengan angaran yang terbatas, sehingga pemprov DKI Jakarta hanya dapat menayangkan iklan tersebut di dua stasiun televisi dan hanya berdurasi selama dua bulan, seperti yang diungkapkan oleh Bapak Yuliarto: "Kami berharap semua televisi mau menayangkan PSA Busway dengan tanpa biaya. Namun ternyata untuk penayangan PSA ini tidak ada yang gratis, semua harus menggunakan biaya. Mengingat dana yang tersedia sangat terbatas, maka untuk tahun 2010 tayangan PSA ini hanya di 2 stasiun televisi. Oleh sebab itu kami memilih Metro TV dan TV One sebagai stasiun televisi yang menayangkan PSA busway. Menurut hemat kami kedua stasiun televisi ini memiliki misi yang bersifat informative lebih besar dibandingkan hiburan dan pendidikan.”

Penuturan dari Bapak Yuliarto sesuai dengan penjelasan mengenai kekurangan dari media televisi adalah faktor biaya. Menurut Vivian (2008), biaya produksi dan penayangan suatu program di media televisi relatif lebih mahal dibandingkan media lainnya, namun media televisi dapat memberikan dampak yang hebat dan menjangkau audien massa yang beragam. Dari pembahasan tersebut penulis menarik kesimpulan bahwa pemprov DKI Jakarta mengandalkan media televisi walaupun dengan biaya yang mahal dan terbentur anggaran yang terbatas, namun diharapkan iklan tersebut dapat menjangkau target yang ditujukan.

Selain penayangan iklan layanan masyarakat mengenai busway yang ditayangkan pada saat prime time, untuk menarik perhatian masayarakat pemprov DKI Jakarta yang berkerja sama dengan sebuah production house, menggunakan artis di dalam iklan tersebut. Seperti yang dituturkan oleh Bapak Rinta: "Kami berkerjasama dengan production house dalam memproduksi PSA busway ini, pihak mereka yang mendesain dan merancang PSA tersebut, setelah rancangan atau stroryboard jadi, pihak kami menganalisa storyboard yang mereka ajukan, jika iklan tersebut sesuai dengan pesan yang kami inginkan, ya kami terima dan diproduksi. Didalam iklan busway ini sendiri kan ada artisnya, ada public figure-nya, hal tersebut merupakan salah satu cara kami menarik perhatian masyarakat, disamping jadwal penayangan pada prime time.”

Penggunaan sebuah artis dalam iklan layanan masyarakat ini dimaksudkan untuk menarik perhatian masyarkat menonton iklan yang ditayangkan, sesuai dengan teori komunikasi persuasi yang menyebutkan bahwa "iklan merupakan bentuk kegiatan komunikasi non personal yang disampaikan lewat media dengan membayar ruang yang dipakainya untuk menyampaikan pesan yang bersifat membujuk (persuasi) kepada konsumen oleh perusahaan, lembaga non komersial, maupun pribadi yang berkepentingan” (Widyatama, 2005, p. 15).

Selain itu penggunaan artis dalam iklan tersebut akan mempengaruhi kualitas iklan tersebut di mata masyarakat, "Citra (image) persuader dalam komunikasi persuasif sangat menentukan dalam mengubah, membentuk dan memperkuat sikap, pendapat dan perilaku sasaran sesuai dengan tujuan yang diinginkan, citra persuader berbanding lurus dengan kredibilitasnya" (Soemirat, Satari \& Suryana, 2007).

Selain itu, pemprov DKI Jakarta menggunakan salah satu metode komunikasi persuasi dalam iklan yang ditayangkan, yaitu Metode asosiasi, dalam metode ini penyajian suatu "message" yang dihubungkan dengan suatu peristiwa atau obyek yang popular, yang menarik perhatian publik" (Abdurrachman, 2001, p. 70).

Selain itu, untuk menarik perhatian masyarakat iklan layanan masyarakat dibuat dengan durasi yang tidak terlalu panjang, seperti yang diungkapkan oleh Bapak Yuliarto: "Cara kami dalam menarik minat masyarakat untuk menonton atau melihat tayangan PSA Busway yang kami produksi, seperti (PSA) dibuat menarik dengan mengetengahkan artis tentunya artis yang sudah dikenal wajahnya oleh masyarakat atau publik figure, kemudian PSA dibuat dengan durasi tidak terlalu lama sehingga 
penonton tidak jenuh untuk melihatnya. Dan juga PSA ditayangkan pada program televisi yang menjadi unggulan di Metro TV dan TV One. Atau dengan kata lain program televisi yang banyak jumlah penontonnya.”

Penuturan Bapak Yuliarto sesuai dengan pembahasan teori yang ada, bahwa "Sekarang ini para pembuat iklan televisi tidak lagi membuat iklan yang panjang-panjang, mereka justru membuat iklan pendek dan menarik. Agar ketika ditayang ulang, pemirsa tidak cepat bosan. Iklan dengan pendekatan emosi yang membikin penasaran pemirsa juga bisa digunakan sebagai teknik untuk lebih diingat oleh pemirsa” (Lee \& Johnson, 2004, p. 267).

Penggunaan artis di dalam iklan layanan masyarakat mengenai transportasi busway ini termasuk kedalam metode komunikasi persuasi, yaitu metode "icing device, Merupakan suatu metode yang menyajikan message dengan menggunakan emotional appeal agar menjadi lebih menarik, dapat memberikan kesan yang tidak mudah dilupakan, lebih menonjol daripada yang lain (Abdurrachman, 2001, pp. 70-71).

Dalam melakukan sosialisasi, pemprov DKI Jakarta bermaksud untuk menyampaikan pesan kepada masyarakat mengai transportasi busway. Pesan yang ingin disampaikan ini dikirimkan oleh pemprov DKI Jakarta ke masyarakat luas salah satunya melalui iklan layanan masyarakat, seperti yang dituturkan oleh Bapak Rinta: "Melalui PSA busway ini kami ingin menyampaikan bahwa busway memliki kelebihan dibandingkan moda trasnportasi lain, seperti keunggulan dari segi keamanan dan kenyamanan, namun dengan tarif yang dapat dijangkau kelas seluruh lapisan masyarakat. Dalam PSA busway itu kan ada artisnya, kami ingin menggambarkan bahwa artis aja mau naik busway, kenapa masyarakat banyak yang masih menggunakan kendaraan pribadi.”

Dari penuturan tersebut, penulis menganalisa bahwa suatu iklan layanan masyarakat menjalankan sebuah fungsinya, yaitu periklanan sebagai sebuah fungsi informasi”(Lee \& Johnson, 2004). Pernyataan tersebut terkandung dalam salah satu prinsip iklan yaitu adanya pesan tertentu yang dikandung oleh sebuah iklan, bahwa "...sebuah iklan tidak akan nada tanpa adanya pesan. Tanpa pesan, iklan tidak akan berwujud. Bila di media cetak, ia hanya ruang kosong tanpatulisan, gambar atau bentuk apapun, bila di media radio, tidak akan terdengar suara apapun, bila di media televisi, tidak terlihat gambar dan suara apapun, maka ia tidak dapat disebut iklan karena tidak terdapat pesan” (Gema Pariwara, 2011).

Melalui iklan layanan masyarakat tersebut, pemprov DKI Jakarta ingin mengajak masyarakat untuk menggunakan busway sebagai alat transportasi sehari-hari untuk mengurangi tingkat kemacetan, hal ini berhubungan dengan teori komunikasi persuasi. Menurut Abdurrachman (2001), "Komunikasi persuasi adalah adalah suatu tindakan yang berdasarkan segi-segi psikologis, yang dapat membangkitkan kesadaran individu. Dinegara-negara demokratis usaha mempengaruhi opini publik, sikap dan tingkah laku hanya diperbolehkan dengan cara-cara persuasif, yaitu dengan menggunakan komunikasi yang informatif” (p. 62).

Selain itu, penayangan iklan tersebut melibatkan seorang artis yang digambarkan sedang menggunakan transportasi busway yang aman, nyaman dan tarif yang terjangkau, hal ini merupakan salah satu keunggulan iklan, bahwa “...karena sifat yang visual dan merupakan kombinasi warnawarna, suara dan gerakan, maka iklan televisi tampak hidup dan nyata. Kelebihan ini tidak dimiliki oleh media lain. Dengan kelebihan ini, para pengiklan dapat menunjukkan dan memamerkan kelebihan atau keunggulan produknya secara detail” (Lee \& Johnson, 2004, p. 267).

\section{Tujuan Program Sosialisasi Menggunakan Media Televisi}

Dari sosialisasi mengenai transportasi busway yang sudah dilakukan ini, pemprov DKI Jakarta tentunya memiliki tujuan yang ingin dicapai. Seperti yang dijelaskan oleh Bapak Rinta terkait tujuan 
dari sosialisasi program transportasi busway: “Tujuan kami dari program sosialisasi melalui PSA ini untuk menambah pengetahuan masyarakat tentang berbagai informasi terkini terkait busway, Kemudian meningkatkan pemahaman masyarakat tentang busway, mengubah opini masyarakat yang semula negatif menjadi positif tentang sarana trasnportasi yang ada, dan yang terkahir mengubah perilaku warga Jakarta yang semula menggunakan kendaraan pribadi sebagaimana alat transportasi menjadi menggunakan busway.”

Penuturan tersebut menjelaskan bahwa sosialisasi transportasi busway melalui iklan layanan masayrakat mempunyai tujuan yaitu pengubahan opini masyarakat dan mengubah prilaku masyarakat yang semula menggunakan kendaraan pribadi beralih menggunakan transportasi busway. Tujuan dari sosialisasi melalui iklan layanan masyarakat ini sesuai dengan teori yang membahas mengenai tujuan komunikasi persusasi, yaitu pengubahan tanggapan. "Pengubahan tanggapan adalah adalah perubahan tanggapan sasaran persuasi untuk mengubah perilaku mereka terhadap suatu produk, konsep atau gagasan” (Soemirat, Satari \& Suryana, 2007).

Berdasarkan penelitian sebelumnya, iklan dapat memperkuat opini seseorang yang sudah terbentuk, iklan yang menampilkan tema remaja terlihat keren tanpa merokok, mungkin saja berhasil dalam meyakinkan seseorang yang tidak merokok memiliki sisi yang lebih baik dalam hal kesehatan jika dia tidak merokok kedepannya (Himawanto, 2004).

Penggunaan iklan layanan masyarakat untuk mengubah opini masyarakat dan mengubah prilaku masyarakat sesuai dengan yang diungkapkan oleh DUNN dan Barban dalam (Widyatama, 2005), "Iklan merupakan bentuk kegiatan komunikasi non personal yang disampaikan lewat media dengan membayar ruang yang dipakainya untuk menyampaikan pesan yang bersifat membujuk (persuasi) kepada konsumen oleh perusahaan, lembaga non komersial, maupun pribadi yang berkepentingan” (p. 15).

Sehingga penulis menarik kesimpulan bahwa pemprov DKI jakarta menggunakan kesan realistik yang menjadi keunggulan iklan layanan masyarakat dalam media televisi dibandingkan media lainnya untuk mengubah opini masyarakat mengenai transportasi yang ada. Oleh karena itu pemprov DKI Jakarta berharap sosialisasi transportasi busway melalui iklan layanan masyarakat dapat ditingkatkan intensitasnya, seperti yang diutarakan oleh Bapak Rinta: "Jika dimungkinkan kami tentunya berharap tayangan PSA di stasiun televisi ini sesering mungkin dan jangka waktu yang cukup lama, bahkan kalau memungkin selama satu tahun penuh namun karena dana yang terbatas sehingga untuk tahun 2010 hanya bulan Juni sampai Agustus.”

Dari penuturan Bapak Rinta, penulis menganalisa bahwa iklan layanan masyarakat bagi pemprov DKI Jakarta memiliki peranan yang cukup penting sebagai sarana sosialisasi, terkait sosialisasi transportasi busway. Namun, permasalahan dana yang terbatas menjadi hambatan bagi pemprov DKI Jakarta untuk dapat menayangkan iklan tersebut lebih lama lagi. seperti yang sudah dibahas sebelumnya bahwa "biaya produksi dan penayangan suatu program di media televisi relatif lebih mahal dibandingkan media lainnya, namun media televisi dapat memberikan dampak yang hebat dan menjangkau audien massa yang beragam” (Vivian, 2008, p. 373).

Terlepas dari biaya yang relatif lebih mahal dalam menggunakan iklan layanan masyarakat dalam media televisi dibandingkan media lainnya, iklan layanan masyarakat dalam media televisi memiliki keunggulan, seperti kesan relaisitik, repitisi/pengulangan dan dapat mencakup masyarakat luas. Hal tersebut yang menjadi pertimbangan pemprov DKI Jakarta dalam mengandalkan iklan layanan masyarakat sebagai sarana sosialisasi program transportasi busway. Seperti yang diutarakan oleh Bapak Rinta: “...menurut saya media televisi memiliki peranan yang cukup besar dalam memberikan pemahaman kepada masyarakat terkait busway. Melalui PSA di televisi kami dapat menyampaikan informasi dan ajakan untuk menggunakan busway kepada masyarakat luas. Hal ini dapat dilihat dari sudah banyak masyarakat Jakarta yang menggunakan busway, namun belum semua 
masyarakat jakarta menggunakan busway tersebut. Permasalahannya orang-orang yang menggunakan trasnportasi busway kebanyakan orang yang tidak mempunyai kendaraan pribadi, kami inginnya orang yang menggunakan kendaraan pribadi juga menggunakan busway. Untuk itu kami akan terus melakukan sosialisasi melalui berbagai media, terutama PSA di televisi agar masyarakat luas mengetahui informasi dan perkembangan terbaru mengenai busway ini.”

Dari penturan Bapak Rinta, penulis menganalisa bahwa iklan layanan masyarakat dapat membantu pemprov DKI Jakarta dalam mencapai salah satu tujuan dari program sosialisasi yang telah dilakuakn, yakni pengubahan opini atau tanggapan. Hal tersebut sesuai dengan teori mengenai periklanan yaitu “...iklan merupakan bentuk kegiatan komunikasi non personal yang disampaikan lewat media dengan membayar ruang yang dipakainya untuk menyampaikan pesan yang bersifat membujuk (persuasi) kepada konsumen oleh perusahaan, lembaga non komersial, maupun pribadi yang berkepentingan” (Widyatama, 2005, p. 15).

Berdasarkan penelitian sebelumnya, iklan berhasil mempengaruhi dan memperkuat opini seseorang mengenai suatu hal, iklan antirokok ini dapat saja berhasil bagi mereka yang memang belum mengenal rokok. Menurut Himawanto (2004), berdasarkan variabel yang sudah dijabarkan sebelumnya, para remaja yang belum mengenal rokok akan merasa lebih baik dan menjauhkan dirinya dari kerugian yang ditimbulkan dari prilaku merokok, baik resiko kesehatan maupun resiko sosial.

Seperti yang sudah dibahas sebelumnya bahwa "iklan mengandung unsur yang bersifat membujuk (persuasi) dan di dalam komunikasi persuasi itu sendiri terdapat tujuan salah satu tujuannya adalah pengubahan tanggapan” (Soemirat, Satari \& Suryana, 2007). Tujuan dari sosialisasi yang dilakukan oleh pemprov DKI Jakarta dengan menggunakan iklan layanan masyarakat sesuai dengan teori yang ada. Hal tersebut diperkuat karena "Iklan televisi bisa ditayangkan beberapa kali dalam sehari sampai dipandang cukup bermanfaat yang memungkinkan sejumlah masyarakat untuk menyaksikannya, dan dalam frekuensi yang cukup sehingga pengaruh iklan itu muncul” (Lee \& Johnson, 2004, p. 267).

Selain itu, menurut pemprov DKI Jakarta, sosialisasi yang telah dilakukan melalui iklan layanan masyarakat dianggap dapat mempengaruhi masyarakat dalam mengubah opini masyarakat mengenai kondisi transportasi yang telah mengalami sedikit perbaikan dengan keberadaan transportasi busway, hal ini sesuai dengan teori efek komunikasi massa yang menyebutkan bahwa komunikasi massa mengandung efek kognitif. Menurut Karlinah, Soemirat \& Komala (1999), "Efek kognitif adalah akibat yang timbul pada diri komunikan yang sifatnya informatif bagi dirinya. Dalam efek kognitif ini akan dibahas tentang bagaimana media massa dapat membantu khalayak dalam mempelajari informasi yang bermanfaat dan mengembangkan keterampilan kognitif. Melalui meda massa, kita memperoleh informasi tentang benda, orang, atau tempat yang belum pernah kita kunjungi secara langsung” (p. 87).

Dari pembahasan tersebut penulis dapat menarik kesimpulan bahwa pemprov DKI Jakarta memiliki tujuan untuk mengubah opini masyarakat mengenai keadaan transportasi di Jakarta dengan menggunakan iklan layanan masyarakat sebagai sarana penyampaian pesan untuk mencapai tujuan tersebut. Iklan layanan masyarakat dalam media televisi dapat membantu pemprov DKI Jakarta dalam rangka mencapai tujuan tersebut, dikarenakan iklan layanan masyarakat dalam media televisi ditayangkan tidak hanya sekali dan ditambah dengan kesan realistik yang memperlihatkan bahwa transportasi busway berbeda dengan sarana transportasi lainnya, karena memiliki keunggulan dalam hal kenyamanan, kemanan dan tarif yang terjangkau.

Namun, untuk mencapai tujuan yang selanjutnya yaitu perubahan prilaku, pemprov DKI Jakarta menyadari bahwa iklan layanan masyarakat belum dapat mengubah prilaku masyarakat untuk beralih dari menggunakan kendaraan pribadi menjadi menggunakan busway sebagai alat transportasi. Seperti yang diutarakan oleh Bapak Yuliarto: "Disadari memang bahwa sosialisasi busway melalui 
media televisi belum dapat sepenuhnya merubah sikap warga Jakarta yang semula menggunakan kendaraan pribadi atau mobil pribadi sebagai alat trasportasi beralih menggunakan busway, hal tersebut disebabkan oleh anggaran biaya yang terbatas. Namun demikian dengan anggaran yang terbatas, melalui penayangan PSA Busway di TV One dan Metro TV, kami berusaha agar pesan yang ingin kami sampaikan dapat diketahui oleh masyarakat luas. Hal tersebut akan menambah pemahaman masyarakat tentang perkembangan busway sebagai angkutan transportasi massa.”

Dari penuturan Bapak Rinta, penulis menganalisa bahwa iklan layanan masyarakat belum dapat berperan untuk mengubah prilaku masyarakat, hal ini dilihat dari masih tingginya angka kemacetan di kota Jakarta. Pernyataan tersebut sesuai dengan peneltian sebelumnya yang menyebutkan bahwa pemikiran keyakinan yang sudah terbentuk di dalam benak setiap orang tentunya sulit dirubah begitu saja hanya dengan menyaksikan tayangan iklan di televisi (Himawanto, 2004).

Keterbatasan anggaran menjadikan pemprov DKI Jakarta terbatas untuk menayangkan iklan layanan masyarakat ini, hal tersebut seperi yang dijelaskan menurut Morissan (2008), mahalnya biaya iklan di televisi menyebabkan perusahaan dengan anggaran terbatas akan sulit untuk beriklan di televisi. Salah satu hambatan untuk mencapai tujuan tersebut adalah permasalahan anggaran yang terbatas. Sehingga keterbatasan anggaran tidak memungkinkan pemprov DKI Jakarta untuk menayangkan iklan layanan masyarakat ini untuk jangka waktu yang lebih lama dan menggunakan stasiun televisi yang lebih banyak lagi, sehingga dapat menambah intensitas penayangan iklan layanan masyarakat ini. Seperti yang diungkapkan oleh Bapak Rinta: "Menurut saya, hal yang sangat berperan dalam mensosialisasikan busway terutama adalah Dana atau anggaran yang tersedia, kemudian pengemasan pesannya atau informasinya, diupayakan menggunakan kalimat yang singkat, padat, jelas sehingga memudahkan penonton untuk penerima pesan atau informasi busway tersebut, dan juga Jadwal pentayangannya beserta frekuensi/volume pentayangan.”

Dari penuturan tersebut semakin memperjelas bahwa anggaran, pengemasan pesan dan intensitas penayangan iklan, memiliki pengaruh yang cukup kuat dalam mencapai keberhasilan suatu iklan. Hal tersebut sesuai dengan teori yang ada bahwa, "sekarang ini para pembuat iklan televisi tidak lagi membuat iklan yang panjang-panjang, mereka justru membuat iklan pendek dan menarik. Agar ketika ditayang ulang, pemirsa tidak cepat bosan. Iklan dengan pendekatan emosi yang membikin penasaran pemirsa juga bisa digunakan sebagai teknik untuk lebih diingat oleh pemirsa” (Lee \& Johnson, 2004, p. 267).

Dari pembahasan tersebut, penulis menarik kesimpulan bahwa bagi pemprov DKI Jakarta iklan layanan masyarakat dapat menjalankan tugasnya sebagai pengubah opini masyarakat dalam sosialisasi yang sudah dilakukan, namun untuk mencapai tujuan dalam hal mengubah prilaku masyarakat masih diperlukan peningkatan. Hal utama yang perlu ditingkatkan adalah dalam penambahan anggaran, penambahan anggaran akan mendukung iklan ini menjadi lebih menarik dan menambah intensitas atau frekuensi penayangan iklan tersebut.

\section{Proses Identifikasi Masalah}

Dalam perencanaan komunikasi suatu program sosialisasi, pemprov DKI Jakarta terlebih dahulu mengidentifikasi masalah melalui pemantauan opini yang sedang berkembang, terkait sosialisasi transportasi busway, diskominfomas pemprov DKI Jakarta melakukan pemantauan dari kliping berita, seperti yang dijelaskan oleh Bapak Rinta: “...kami terlebih dahulu memantau opini mengenai transportasi busway yang berkembang di masyarakat melalui kliping berita dan tayangan pemberitaan di media televisi. Selanjutnya, Meminta masukan atau pendapat dari para ahli kehumasan atau komunikasi yang akan akan menjadi stakeholder kami. Kemudian, mempertimbangkan melalui sarana apa sosialisasi tersebut dilakukan, apakah dengan cara sosialisasi secara langsung atau menggunakan media massa. Dalam hal sosialisasi program transportasi busway, pemprov DKI memilih media massa sebagai sarana sosialisasi kepada masyarakat.” 
Dari pernyataan tersebut, penulis menganalisis bahwa pemprov DKI Jakarta dalam melakukan perencanan sosialisasi transportasi busway pada tahap mendefinisikan masalah sesuai dengan teori yang menyebutkan bahwa dalam tahap mendefinisikan masalah, Public Relations perlu melibatkan diri dalam penelitian dan pengumpulan fakta. Selain itu Public Relations perlu memantau dan membaca terus pengertian, opini, sikap dan prilaku mereka yang berkepentingan dan terpengaruh oleh sikap dan tindakan perusahaan. Pemprov DKI Jakarta melibatkan pakar komunikasi dan kehumasan untuk meminta pendapat mengenai situasi yang ada, namun hal tersebut hanya untuk tahapan yang sangat awal. "untuk dapat memberikan masukan, arahan, dan bimbingan yang dilakukan secara teratur kepada anggota asosiasi” (Morissan, 2008, p. 130).

Dalam penentuan stakeholder, pemprov DKI Jakarta tidak melakukan riset terlebih dahulu. Pihak diskominofomas pemprov DKI Jakarta langsung menentukan stakeholder mereka dengan meminta bantuan pakar komunikasi dan kehumasan. Hal tersebut tidak sesuai dengan dengan pembahasan mengenai analisis stakeholder, dalam menganalisis stakeholder diperlukan sebuah riset/penelitian. Hal ini bertujuan untuk mengumpulkan informasi dalam menyusun strategi komunikasi yang akan dilakukan, sehingga dapat mencapai tujuan yang diinginkan (Broom, 2008).

Tanpa melakukan riset terlebih dahulu untuk menganalisa situasi yang ada, tentunya data yang di dapat belum tentu akurat. "Tanpa melakukan riset terlebih dahulu praktisi humas memiliki keterbatasan untuk mengetahui situasi yang tengah mereka hadapi, situasi hanya akan dilihat secara sepotong-sepotong” (Morissan, 2008, p. 112).

Dari analisis tersebut, penulis menarik simpulan bahwa pemprov DKI Jakarta hanya melakukan pemantauan opini melalui kliping berita dan tayang berita mengenai transportasi busway, tanpa melakukan penelitan langsung kepada masyarakat mengenai opini mereka terhadap kondisi transportasi busway. Dalam melakukan proses analisis situasi untuk sosialisasi program transportasi busway, pemprov DKI Jakarta melibatkan pakar komunikasi yang menjadi stakeholder dan membantu pemprov DKI Jakarta dalam perencanaan komunikasi yang akan dilakukan, tanpa melakukan riset terlebih dahulu untuk menganalisa permsalahan dan situasi yang ada. Sehingga dalam melakukan suatu analisis situasi pemprov DKI Jakarta tidak melakukan langkah yang sesuai dengan teori yang ada.

\section{Proses Perencanaan dan Pemograman}

Setelah melakukan proses analisis situasi dan penentuan pemilihan media, terkait fokus penelitian penulis adalah iklan layanan masyarakat dalam media televisi, pemprov DKI Jakarta melakukan langkah selanjutnya, yaitu perencanaan komunikasi dan penyusunan anggaran. Seperti yang dijelaskan oleh Bapak Rinta: “...hal yang kami rencanakan dalam pembuatan program sosialisasi busway ini meliputi bentuk sosialisasi akan seperti apa, apakah sosialisasi langsung atau melalui media, kemudian target yang ingin dicapai dalam sosialisasi ini, pemilihan media yang akan digunakan apakah media televisi, radio atau media internet, kapan waktu sosialisasi akan dilakukan, berapa lama waktu sosialisasi tersebut, pihak mana saja yang akan kami ajak kerja sama untuk membantu kami dalam melakukan sosialisasi mengenai program transportasi busway, dan perencanaan tersebut akan disusun kedalam proposal dan diajukan ke dewan (DPRD DKI Jakarta) untuk mendapatkan anggaran yang kami perlukan. Kurang lebih hal-hal seperti itu yang kami rencanakan.”

Dari penuturan Bapak Rinta, penulis menganalisis bahwa setelah melakukan proses analisis situasi, pemprov DKI Jakarta melakukan tahapan selanjutnya, yaitu perencanaan dan pemograman. Hal ini sesuai dengan teori yang membahas mengenai langkah-langkah ini dirumuskan dalam bentuk rencana dan program, termasuk anggarannya. Sesuai dengan teori yang menyebutkan bahwa dalam tahapan ini, "humas menetapkan tujuan, mempertimbangkan alternatif, menilai resiko, memutuskan arah dan tindakan, menetapkan anggaran dan mendapatkan persetujuan” (Morissan, 2008, p. 148). 
Dalam proses perencanaan ini, pemprov DKI Jakarta menentukan strategi dan taktik dalam menyampaikan komunikasi untuk mencapai tujuan yang diinginkan. Seperti bentuk sosialisasi, tujuan sosialisasi, pemilihan media sebagai sarana sosialisasi, waktu sosialisasi dan jangka waktu sosialisasi tersebut berlangsung. Hal ini seperti yang dijelaskan dalam perencanaan strategis oleh sebuah PR. Dalam perencanaan strategis sebuah PR melibatkan keputusan tentang tujuan dan sasaran program, mengidentifikasi publik kunci, menentukan kebijakan atau aturan untuk memandu pemilihan strategi, dan menentukan strategi (Broom, 2008).

Sedangkan dalam perencanaan penyajian pesan, terkait perencanaan penyampaian komunikasi melalui iklan layanan masyarakat dalam media televisi, proses perencanaan yang dilakukan meliputi bentuk tayangan, penyajian pesan dan durasi iklan tersebut, seperti yang dijelaskan oleh Bapak Yuliarto: “...untuk secara keseluruhan mengenai perencaanan program sosialisasi busway, atasan saya yang lebih berhak untuk menjawab pertanyaan tersebut. Tetapi jika perencanaan sosialisasi program busway dengan menggunakan televisi kami merencanakan mengenai bentuk tayangan apa yang akan digunakan dimedia televisi, apakah running text, dialog interaktif atau menggunakan PSA. Kemudian penyampaian pesan, bentuk pesannya apakah akan ditampilkan pesan kata yang lebih banyak dibandingkan dengan gambar atau sebaliknya, kemudian berapa lama Durasi penayangan PSA, kami juga mendiskusikan untuk Penyajiannya apakah dalam PSA tersebut akan menampilkan pejabat dilingkungan pemprov DKI jakarta untuk menyampaikan statement atau hanya menampilkan artis ibukota, kemudia jadwal pentayangan PSA dan pemilihan stasiun TV yang akan kami ajak kerjasama. Kami juga mempertimbangkan artis yang akan ditampilkan pada tayangan PSA tersebut, namun semua ini disesuaikan dengan dana yang tersedia, hal mengenai konsep iklan dan produksi kami akan berkerjasama dengan sebuah production house yang akan memproduksi iklan tersebut.”

Dari penuturan tersebut penulis menganalisis bahwa perencanaan pesan yang akan disampaikan merupakan salah satu bagian yang terpenting dalam proses perencanaan program sosialisasi. Hal ini melengkapi proses perencanaan yang telah disebutkan sebelumnya oleh bapak rinta perencanaan mengenai bentuk sosialisasi, sarana sosialisasi, tujuan sosialisasi, dan anggaran. Hal ini sesuai dengan teori yang menyebutkan “...bahwa, selain pemikiran anggaran terdapat beberapa hal yang harus dipikirkan oleh seorang PR, meliputi komunikator, pesan, media dan publik yang dituju” (Abdurrachman, 2001, p. 32).

Dari pembahasan tersebut, penulis menarik kesimpulan bahwa pihak pemprov DKI Jakarta telah melakukan well-planned dalam proses perencanaan komunikasi mengenai program sosialisasi transportasi busway. Hal tersebut didasarkan pada elemen-elemen yang direncanakan oleh pihak diskominfomas pemprov DKI Jakarta sesuai dengan teori yang ada, proses perencanaan tersebut meliputi tujuan program, bentuk program komunikasi, pesan yang ingin disampaikan, melalui saluran apa pesan tersebut disampaikan, media yang akan digunakan, kapan program tersebut akan dilakukan dan juga kepada siapa pesan tersebut disampaikan.

\section{Implementasi Strategi}

Setelah pengumpulan data-data dan melakukan proses perencanaan, pihak diskominfomas mengimplemantasikan perencanaan tersebut ke dalam sebuah tindakan, yaitu program sosialisasi transportasi busway yang dilakukan melalui media massa. Terkait fokus penelitian penulis, penulis hanya membahas mengenai program sosialisasi yang dilakukan melalui iklan layanan masyarakat dalam media televisi. Dalam tahap ini merupakan tahap pelaksanaan/kegiatan sesuai dengan fakta dan data yang telah dirumuskan dalam bentuk perencanaan. Pada tahap ini, aksi dan komunikasi harus dikaitkan dengan objective dan goals yang spesifik (Broom, 2008).

Program sosialisasi yang dilakukan selama dua bulan pada periode bulan Juni-Agustus 2010, dan ditayangkan melalui iklan layanan masyarakat dalam media televisi sebanya 4-7 kali sehari, 
merupakan aksi dalam strategi yang telah direncanakan. Pemprov DKI Jakarta berkerjasama dengan stasiun televisi TV One dan Metro TV dalam melakukan program sosialisasi transportasi busway, pemilihan media ini sebagai strategi dalam mencapai tujuan yang diinginkan, seperti yang dijelaskan oleh Bapak Rinta: “...jadi begini, dalam memilih media yang akan menyiarkan iklan busway ini, kami tidak memiliki perencaan, namun kami memiliki beberapa kriteria dalam pemilihan media yang akan menyiarkan iklan pemprov DKI, dan kedua stasiun televise tersebut sesuai dengan kriteria yang pihak kami tentukan, seperti Metro TV dan TV One itu media televisi yang misinya sebagian besar untuk menyampaikan informasi yang bersifat informatif dibandingkan hiburan. Hal ini dapat dilihat bahwa program yang disajikan di TV One dan Metro TV sedikit menayangkan senetron atau musik. Penonton TV One dan Metro TV cenderung tingkat ekonominya termasuk kelompok menengah keatas, Sedangkan masyarakat yang menggunakan kendaraan pribadi cenderung kelompok menengah keatas. Selain itu, pada jam-jam sibuk (prime time) di stasiun Metro TV dan TV One lebih banyak menyajikan program televisi yang bersifat informatif.”

Dari pernyataan tersebut, penulis menganalisis bahwa pemilihan media yang dilakukan oleh pemprov DKI Jakarta lebih kepada target audiens yang spesifik, yaitu masyarakat kelas menengah dan atas yang memiliki kendaraan. Hal ini sesuai dengan tujuan pemprov DKI Jakarta yang mengingkan agar masyarakat yang memiliki kendaraan probadi beralih menggunakan sarana trasnportasi busway sebagai alat transportasi sehari-hari. Dalam pelaksanaan program sosialisasi melalui iklan layanan masyarakat dalam media televisi, pemprov DKI Jakarta membentuk suatu tim kerja yang bertanggung jawab dalam memberikan laporan dari hasil patauan selama program sosialisasi tersebut berlangsung. Seperti yang diutarakan oleh Bapak Rinta: "Dalam melaksanakan suatu kegiatan senantiasa pihak kami membentuk suatu Tim Kerja. Dan tim kerja inilah yang secara intensif memantau pentayangan PSA yang kami tayangkan dan tim kerja ini yang memberikan laporan kepada saya mengenai kelangsungkan kegiatan sosialisasi transportasi busway melalui PSA di media televisi. Tim kerja ini terdiri dari staf bagian televisi. Selain itu terdapat seksi Publikasi yang juga membantu melakukan pemantauan.”

Dari pernyataan tersebut penulis menganalisa bahwa pembuatan suatu tim kerja dalam melakukan program sosialisasi transportasi busway ini bertujuan untuk bertindak responsif dan tim kerja tersebut yang bertanggung jawab pada saat program sosialisasi tersebut berlangsung. Hal tersebut merupakan komponen aksi dalam strategi dalam mengambil tindakan dan berkomunikasi. Sesuai dengan yang dijelaskan dalam rencana implementasi program, siapa yang akan bertanggung jawab terhadap setiap tindakan dan taktik komunikasi (Broom, 2008). Selain dari pada aksi dalam strategi, terdapat komunikasi dalam strategi. Komunikasi dalam strategi merupakan komponen yang lebih nyata dan berfungsii menginterpretasikan dan mendukung strategi aksi (Broom, 2008). Dalam program sosialisasi transportasi busway yang dilakukan oleh pemprov DKI Jakarta, pihak diskominfomas menggambarkan bahwa transportasi busway merupakan sarana transportasi yang aman, nyaman dan dengan tarif yang terjangkau.

Selain itu, dalam iklan layanan masyarakat tersebut, melibatkan seorang artis dalam proses produksinya. Hal ini merupakan salah satu cara yang dilakukan oleh pihak pemprov DKI Jakarta untuk menarik perhatian masayrakat. Seperti yang dijelaskan oleh Bapak Yuliarto: "Melalui PSA busway ini kami ingin menyampaikan bahwa busway memliki kelebihan dibandingkan moda trasnportasi lain, seperti keunggulan dari segi keamanan dan kenyamanan, namun dengan tarif yang dapat dijangkau kelas seluruh lapisan masyarakat. Dalam PSA busway itu kan ada artisnya, kami ingin menggambarkan bahwa artis aja mau naik busway, kenapa masyarakat banyak yang masih menggunakan kendaraan pribadi. oleh karena itu, kami ingin masyarakat mengajak masyarakat untuk memanfaatkan sarana trasnportasi busway.”

Dari penuturan tersebut, penulis menganalisis bahwa pemprov DKI Jakarta dalam mengkomunikasikan program transportasi busway ini, menyampaikan pesan yang sesuai dengan salah "satu prinsip pembingkaian pesan untuk komunikasi yaitu mengetahui kebutuhan, kepentingan dan 
perhatian dari publik sasaran” (Broom, 2008, p. 392). Sehingga pesan yang disampaikan sesuai dengan harapan masyarakat mengenai kondisi perbaikan sarana transportasi. Tujuan dari dilakukannya program sosialisasi ini adalah untuk mengubah opini masyarakat mengenai kondisi transportasi massa dan mengubah prilaku masyarakat yang tadinya menggunakan kendaraan pribadi beralih menggunakan sarana transportasi busway, dan program sosialisasi ini ditujukan kepada masyarakat kelas menengah dan atas yang memiliki kendaraan pribadi.

Dari pembahasan tersebut penulis menarik simpulan bahwa dalam tahapan melakukan tindakan dan berkomunikasi (implementasi strategi), pihak pemprov DKI Jakarta telah melakukan aksi dan komunikasi yang sesuai dengan teori yang ada. Aksi yang dilakukan seperti pemilihan media dan jangka waktu yang ditentukan serta komunikasi yang dilakukan dalam menyampaikan pesan yang mengandung makna dan kejelasan sesuai dengan target audience yang dituju dan tujuan yang ingin dicapai pemprov DKI Jakarta dalam melakukan program transportasi busway ini.

\section{Proses Evaluasi}

Setelah melalui tahapan identifikasi masalah, perencanaan, serta aksi dan komunikasi, pemprov DKI Jakarta melakukan evaluasi terhadap sosialisasi yang telah dilakukan. dalam melakukan tahapan ini pemprov DKI Jakarta selalu melakukan evaluasi setelah melakukan suatu program, termasuk evaluasi program sosialisasi transportasi busway melalui iklan layanan masyarakat dalam media televisi. seperti yang dikatakan oleh Bapak Rinta: "Setiap melaksanakan kegiatan sosialiasi kami senatiasa melaksanakan evaluasi. Demikian pula halnya dengan sosialisasi program transportasi busway melalui PSA di media televisi. Evaluasi perlu dilakukan guna perbaikan penyajian sosialisasi pada masa yang akan datang. Namun kegiatan evaluasi ini hanya sebatas mengenai jalannya program sosialisasi yang kami lakukan, tanpa melakukan evaluasi langsung bagaimana hasil yang diperoleh melalui PSA ini.”

Dari penuturan yang disampaikan bapak rinta, penulis menganalisis bahwa pemprov DKI Jakarta hanya melakukan evaluasi terkait jalannya program sosialisasi tersebut, tanpa melakukan penelitian mengenai hasil dari program sosialisasi yang dilakukan. Menurut Broom (2008), ”Dalam melakukan proses evaluasi terdapat beberapa kriteria yang dianggap sebagai langkah penting untuk mengetahui hasil dari program yang telah dilakukan, seperti pengukuran jumlah orang yang mengetahui isi pesan, jumlah orang yang mengubah sikapnya, jumlah orang yang bertindak sesuai dengan apa yang diinginkan, dan jumlah orang yang mengulangi atau mempertahankan prilaku yang diharapkan” (pp. 430-432).

Dari pembahasan tersebut, penulis menarik kesimpulan bahwa proses evaluasi yang dilakukan oleh pemprov DKI Jakarta tidak sesuai dengan teori yang ada. Karena dalam pembahasan evaluasi yang dilakukan, pembahasan tersebut hanya membahas mengenai jalannya program dan hal teknis terkait sosialisasi program transportasi busway yang dilakukan. diskominfomas pemprov DKI Jakarta tidak melakukan pembahasan mengenai dampak dari iklan yang telah ditayangkan sebagai sarana sosialisasi transportasi busway. Sehingga sulit untuk mendapatkan data yang pasti mengenai apakah tujuan yang diinginkan telah tercapai. Jika hanya membandingkan data statistik antara pengguna transportasi busway pada saat iklan layanan masayrakat tersebut ditayangkan.

Bagi pihak pemprov DKI Jakarta sendiri menilai bahwa sosialisasi yang telah dilakukan melalui iklan layanan masyarakat dalam media televisi telah mencapai salah satu tujuan mereka yaitu mengubah opini. Hal ini hanya dilihat dengan cata membandingan jumlah angka pengguna busway pada saat iklan tersebut ditayangkan. Seperti yang dijelaskan oleh Bapak Rinta: “Terus terang untuk mengetahui secara pasti apakah sosialisasi melalui tayangan PSA busway ini sudah mencapai tujuan sebagaimana yang diharapkan, kami belum melakukan penelitian dan pemantauan secara langsung ke lapangan/masyarakat. Namun demikian berdasarkan data di BLU TransJakarta bahwa jumlah 
penumpang busway mengalami peningkatan. Dengan demikian kami berkesimpulan bahwa meningkatnya jumlah penumpang busway tersebut didukung oleh adanya sosialisasi tentang Busway.”

Dari pernyataan tersebut penulis menganalisa bahwa proses evaluasi yang dilakukan oleh pemprov DKI Jakarta tidak sesuai dengan teori yang ada. Dalam teori yang ada menyebutkan bahwa dalam "proses evaluasi terdapat proses evaluasi perencanaan, implementasi, dan dampak program, hal tersebut dinamakan riset evaluasi” (Broom, 2008, p. 415).

Pemprov DKI Jakarta hanya melakukan evaluasi perencanaan dan evaluasi implemantasi, tanpa melakukan evaluasi secara langsung dampak dari program sosialisasi yang telah dilakukan. hal yang sama diutarakan oleh Bapak Yuliarto: "Tujuan sosialisasi adalah meningkatkan pemahaman serta merubah sikap masyarakat. Berdasarkan data yang saya peroleh dari BLU bahwa telah terjadi kenaikan penumpang.”

Dari pernyataan tersebut penulis menganalisis bahwa pemprov DKI Jakarta menilai program sosialisasi yang dilakukan telah mencapai tujuan yang diingkan. Hal tersebut dilihat dari data statistik yang terdapat di badan layanan umum (BLU) pada saat iklan tersebut ditayangkan. Hal ini berbeda dengan teori yang ada, yang menyebutkan bahwa "proses Public Relations selalu dimulai dari mengumpulkan fakta dan diakhiri pula dengan pengumpulan fakta, data dan fakta ini diambil berdasarkan sebuah survey yang diadakan secara kontinu untuk mendapatkan umpan balik mengenai program tersebut berhasil atau tidak" (Abdurrachman, 2001, p. 33).

Dari pembahasan tersebut, penulis menarik kesimpulan bahwa dalam melakukan proses evaluasi pemprov DKI Jakarta hanya melakukan evaluasi mengenai perencanaan dan implementasi, tanpa melakukan evaluasi secara mendalam mengenai dampak dari program sosialiasi yang telah dilakukan. Dalam evaluasi yang dilakukan, pihak pemprov DKI Jakarta menilai bahwa program sosialisasi yang telah dilakukan mencapai tujuan yaitu pengubahan opini. Hal tersebut hanya dilihat dengan cara membandingkan data statistik badan layanan umum (BLU) transjakarta dengan masa tayang iklan layanan masyarakat tersebut. Tanpa memperhatikan elemen lainnya pada sebuah PR dalam melakukan proses evaluasi seperti pengukuran jumlah orang yang mengetahui isi pesan, jumlah orang yang mengubah sikapnya, jumlah orang yang bertindak sesuai dengan yang diinginkan dan jumlah orang yang mengulangi atau mempertahankan prilaku yang diharapkan.

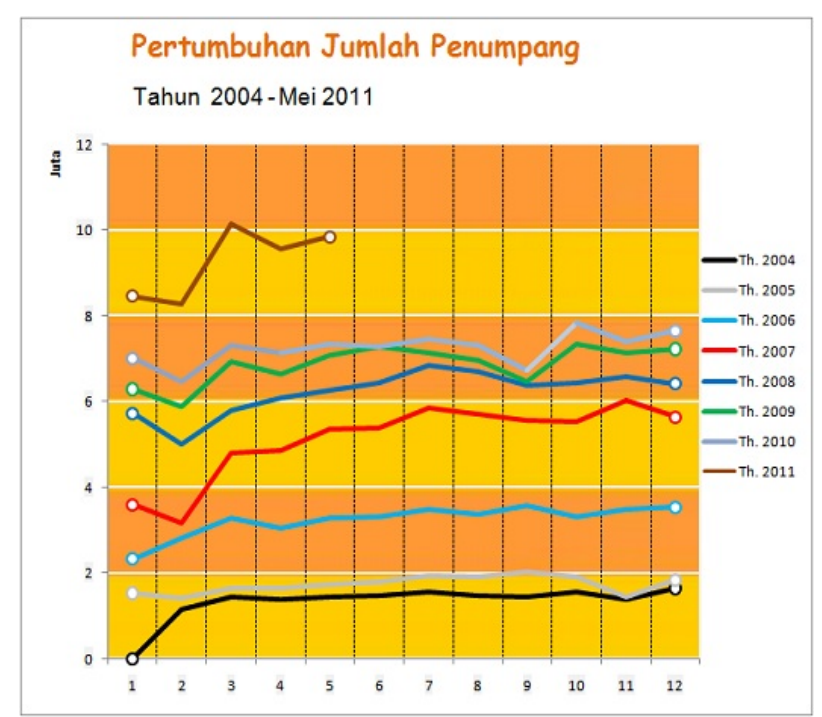

Gambar 1 Statistik jumlah penumpang transportasi busway Sumber: Transjakarta (2011) 


\section{PENUTUP}

Berdasarkan dari data hasil wawancara dan analisa serta pembahasan yang sudah penulis lakukan, penulis dapat menarik simpulan mengenai peran iklan layanan masyarakat di media televisi sebagai sarana sosialisasi program pemprov DKI Jakarta dan proses sosialisasi dilakukan oleh pemprov DKI Jakarta dengan menggunakan iklan layanan masyarakat dalam mensosialisasikan program transportasi busway.

Peran iklan layanan masyarakat sebagai sarana sosialisasi program pemprov DKI Jakarta, di antaranya yaitu bahwa iklan layanan masyarakat memiliki peran yang besar bagi pemprov DKI jakarta sebagai sarana sosialisasi program transportasi busway karena dapat mencakup masyarakat luas, hal ini sesuai dengan prinsip pemprov DKI Jakarta dalam melakukan suatu program sosialisasi. Dengan menggunakan iklan layanan masyarakat di media televisi, pemprov DKI mencapai salah satu tujuan dari program sosialisasi yang dilakukan, yaitu mampu untuk mengubah opini masyarakat mengenai kondisi transportasi massa dengan keberadaan busway, namun belum berhasil mencapai tujuan untuk mengubah prilaku masyarakat Jakarta agar beralih dari menggunakan kendaraan probadi menjadi menggunakan sarana transportasi busway. Pemprov DKI Jakarta menggunakan keunggulan iklan layanan masyarakat dalam media televisi dalam menyampaikan pesan yang diinginkan dan untuk menarik perhatian masyarakat agar menoton tayangan iklan tersebut, seperti keunggulan penyajian dalam bentuk audio-visual, penayangan iklan yang berulang-ulang dan penggunan artis dalam iklan tersebut sebagai daya tarik dan pembentukan opini di masyarakat.

Proses sosialisasi dilakukan oleh pemprov DKI Jakarta terkait sosialisasi transportasi busway dengan menggunakan iklan layanan masyarakat di media televisi belum dilakukan secara tepat. Hal tersebut dikarenakan dalam proses identifikasi masalah dan evaluasi tidak dilakukan secara tepat dan menyeluruh, sehingga data yang didapat tidak akurat. Selain itu. anggaran yang terbatas menjadi salah satu hambatan pemprov DKI Jakarta dalam proses sosialisasi yang dilakukan.

\section{DAFTAR PUSTAKA}

Abdurrachman, O. (2001). Dasar-dasar public relations. Bandung: Citra Aditya Bakti.

Ardianto, E., \& Erdinaya, L. K. (2004). Komunikasi massa: Suatu pengantar. Bandung: Simbiosa Rakatama Media.

Ardiansyah, F. (2010). Jumlah kendaraan di Jakarta: 11.362 .396 unit! Diakses pada 2010, 20 September, dari: http://areamagz.com/article/read/2010/09/29/jumlah-kendaraan-dijakarta11362396-unit-?sms_ss=twitter

Blake, R. H., \& Harlodsen, E. O. (1979). A taxonomy of concepts in communication. New York: Hastings House.

Broom, G. (2008). Cutlip and Centre’s effective public relations. Prentice Hall.

Bungin, B. (2007). Sosiologi komunikasi. Jakarta: Kencana Prenada Media.

Erna. (2011). Kecepatan jalan di Jakarta turun 25 persen. Diakses pada 2010, 3 November, dari: http://www.beritajakarta.com/2008/id/berita_detail.asp?nNewsId=43942 
Gema Pariwara. (2011). Prinsip-prinsip dasar iklan. Diakses pada 2011, 5 Mei, dari: http://gemapariwara.blogspot.com/2011/04/prinsip-prinsip-dasar-iklan.html

Himawanto, F. (2004). Pola hubungan faktor-faktor yang mempengaruhi dampak tayangan iklan anti rokok terhadap kognisi dan intense remaja: Studi kasus iklan layanan masyarakat anti rokok Phillip Morris dan Japan Tobacco International di MTV. Jakarta: Universitas Indonesia.

Karlinah, S., Soemirat, B., \& Komala, L. (1999). Komunikasi massa. Jakarta: Universitas Terbuka.

Kriyantono, R. (2006). Teknis praktis riset komunikasi. Jakarta: Kencana Predana Media.

Komisi Kepolisian Indonesia. (2009). Jumlah kendaraan bermotor Juni 2009. Diakses pada 2010, 23 Agustus, dari: http://www.komisikepolisianindonesia.com/main.php?page=artikle\&id=1187

Kuswandi, W. (2008). Komunikasi massa. Jakarta: Rineka Cipta.

Lee, M., \& Johnson, C. (2004). Prinsip-prinsip pokok periklanan dalam perspektif global . Jakarta: Prenada Media.

Moleong, L. J. (2006). Metode penelitian kualitatif. Bandung: Remaja Rosdakarya.

Morissan, M. A. (2008). Manajemen public relations. Jakarta: Kencana.

Severin, J. W., \& Tankard, Jr., J. W. (2001). Teori komunikasi: Sejarah metode dan terapan di dalam media massa. Jakarta: Prenada Media.

Soemirat, S., Satari, H. H., \& Suryana, A. (2007). Komunikasi persuasif. Diakses pada 2011, 17 Februari, $\quad$ dari: http://pustaka.ut.ac.id/website/index.php?option=com_content\&view=article\&id=152:skom43 26-komunikasi-persuasif\&catid=29:fisip\&Itemid $=74$

Transjakarta. (2011). Diakses pada 2011, 15 Juni, dari: http://www.transjakarta.co.id/page.php\#tab-5

Vivian, J. (2008). Teori komunikasi massa (8th ed.). Jakarta: Kencana.

Widyatama, R. (2005). Pengantar periklanan. Jakarta: Buana Pustaka Indonesia. 